\title{
THE NEW DEAL WAS NO DEAL
}

\author{
TUDOR SMIRNA*
}

Resumen: En la actualidad, uno de los loci communes de la historia económica es que el New Deal fue el cóctel ideal de políticas ordenadas por el Estado para sacar a la economía de los EE.UU. de la Gran Depresión que comenzó en 1929. La relevancia de esta interpretación ha aumentado enormemente desde la crisis de 2008, que muchos comparan con la crisis de 1929. Existe una demanda casi general para un nuevo New Deal. Este punto de vista es debatido por la Escuela Austriaca de Economía y por otros pensadores liberales. Estos afirman que sólo el libre mercado ofrece las soluciones necesarias para la recuperación económica en cualquier contexto, incluido el actual y la situación prevaleciente en la década de 1930. El presente ensayo pretende ser un nuevo intento de hacer una corta historia revisionista del período 1933-1939.

Palabras clave: Gran Depresión, New Deal, Roosevelt, Escuela Austriaca de Economía, historia económica, revisionismo.

Clasificación JEL: E00, E32, N12, N22, N42.

Abstract: Currently, one of the loci communes of economic history is that the New Deal was the right cocktail of state-mandated policies to pull the US economy out of the Great Depression that begun in 1929. The relevance of this interpretation has increased tremendously since the crisis of 2008 that many compare with the crisis of 1929. There is a quasi-general demand for a new New Deal. This view is contended by the Austrian School of Economics and by other free-market oriented thinkers. They assert that only the free market offers the solutions necessary for economic recovery in any context, including the actual setting and the situation prevalent in the 1930s. This essay is intended as another attempt at a short revisionist history of the 1933-1939 period.

* Master en Economía de la Escuela Austriaca, Universidad Rey Juan Carlos. Address: Speranței 26, Ap. 5, București 020991, Romania.

Procesos de Mercado: Revista Europea de Economía Política Vol. VII, n.․ㅡ 2, Otoño 2010, pp. 37 a 88 
Key words: Great Depression, New Deal, Roosevelt, Austrian School of Economics, economic history, revisionism.

JEL Classification: E00, E32, N12, N22, N42.

The current economic crisis has a series of competing explanations. These are basically the same competing descriptions that claimed explanatory power over the causes of the Great Depression. Since relativism is not an option and truth must reside in one of these explanations and, at the same time, deny all others one has to decide which one is correct. This silver-line of realism and objective truth-seeking take us following a sound epistemological and methodological tradition ${ }^{1}$ to the observation that the task of elucidating a historical question must first solve its theoretical underpinnings.

The gist of economic science, if correctly professed, resides in demonstrating the law of social harmony: that human society can always and everywhere provide for itself, in an orderly and realistic fashion, the goods - indeed, the institutions - that its members desire. The necessary condition of social order is the institution of private property. ${ }^{2}$ There is no need, nor justification, of a supraagency taking over voluntary affairs for the purpose of correcting alleged defects. Moreover, aggressive intervention ${ }^{3}$ into this order will lead, by logic of human action, to accumulating disorder.

These insights offer us a criterion for classifying explanations of historical events. The present essay sets out to show how correct economic theory ${ }^{4}$ can be and is actually used for isolating the

\footnotetext{
1 See Mises (1985).

2 For the justification of private property as the only framework compatible with a harmonious life in society, see Hoppe (1989), Hoppe (2006), Rothbard (1998). Recent interdisciplinary developments argue that private property is necessary but not sufficient for the long-term sustainability of a natural society. See Comănescu (2008), Huerta de Soto (2004), pp. 52-56.

3 For the theory of interventionism, see Mises (1998), chapters XXV-XXXVI, Rothbard (2004), chapter 12 and Power and Market.

4 As developed by the School of Austrian Economics. Mises (1998) and Rothbard (2004) are the two most developed treatises dealing with praxeology, the body of
} 
causes of historical events during the Great Depression and the recent past.

The United States play a crucial role in the economic history of the XX century. The events during the presidency of Franklin Delano Roosevelt provide another great illustration for the theory of interventionism and especially of its particularization, the theory of the business cycle. In this essay we will give special attention to the analysis of the Roosevelt pre-war years (1933-1939).

I

FDR AND THE GREAT DEPRESSION

I pledge you, I pledge myself to a new deal for the American people. ${ }^{5}$

Why, that's just plain stealing, isn't it Mr. President? ${ }^{6}$

The foremost spring of relevant information about the FDR era is the «hectic and tumultuous hurricane of laws and projects and orders in council which came to be known as the Hundred Days. ${ }^{7}$ A first step in elucidating the Roosevelt part of the "Great Duration» 8 is to deduct the economic consequences that would have had to be expected from the supposed enforcement of the decrees. In other words we will try to answer the following question: how did the American economic picture differ, in the presence of these «laws» - supposing they were enforced-, from the situation that would have prevailed in the absence of the «laws and projects and orders» of the Hundred Days and

arguments showing that peaceful human action leads to harmonious production of goods and institutions.

${ }^{5}$ F.D. Roosevelt's Nomination Address, Chicago, Ill., July 2, 1932. Cited in Raico (2001).

6 Senator Thomas P. Gore from Oklahoma answering F.D. Roosevelt on the resolution abrogating the gold clause. Cited in Anderson (1979), p. 317.

7 Flynn (1948), p. 10.

8 Expression taken from Higgs (1997). 
after? Then, corroboration of historical facts can confirm whether the economic analysis was correct or we must adhere to alternative explanations.

\section{II}

\section{THE CONTINUITY OF THE NEW DEAL}

Although the term «New Deal» was coined in Roosevelt's Chicago speech of acceptance of the presidential nomination in 1932, the wide-scale interventionist policies that characterize it were inaugurated by the Hoover regime with the advent of the crisis in 1929. According to Rothbard, President Coolidge is responsible for the seminal inflationism that motivated the intensified interventionism of Hoover and then the fascist hysteria of the Roosevelt years:

If Coolidge made 1929 inevitable, it was President Hoover who prolonged and deepened the depression, transforming it from a typically sharp but swiftly disappearing depression into a lingering and near-fatal malady, a malady «cured» only by the holocaust of World War II. Hoover, not Franklin Roosevelt, was the founder of the policy of the «New Deal»: essentially the massive use of the State to do exactly what Misesian theory would most warn against - to prop up wage rates above their free-market levels, prop up prices, inflate credit, and lend money to shaky business positions. Roosevelt only advanced, to a greater degree, what Hoover had pioneered. The result for the first time in American history, was a nearly perpetual depression and nearly permanent mass unemployment. The Coolidge crisis had become the unprecedentedly prolonged Hoover-Roosevelt depression (Rothbard (1996), p. 79).

Indeed, it may be argued along with the historian Ralph Raico that the New Deal was the consequence of the damage done by Theodore Roosevelt's regime:

It was the age of "progressivism», a vague term, but one that connoted a new readiness to use the power of government for 
all sorts of grand things. H.L. Mencken, the great libertarian journalist and close observer and critic of presidents, compared him to the German kaiser, Wilhelm II, and shrewdly summed him up: «The America that [Theodore] Roosevelt dreamed of was always a sort of swollen Prussia, truculent without and regimented within». (Raico, (2001)).

Robert Higgs argues ${ }^{9}$ that the Great Depression, with its New Deal policies, was a remnant manifestation of the economic regimentation inaugurated in United States by the First World War:

Many of the institutional arrangements created during the Hundred Days merely reactivated programs and agencies employed during World War I. [...] Moreover, the men selected to administer the revised institutions were often those who had played leading roles during 1917-1918, especially the War Industries Board and the Army.

In America's Great Depression, Rothbard evokes Hoover's idea of his part in the New Deal:

Hoover summarized the measures he had taken to combat the depression: higher tariffs, which had protected agriculture and prevented much unemployment, expansion of credit by the Federal Reserve, which Hoover somehow identified with "protection of the gold standard»; the Home Loan Bank system, providing longterm capital to building-and-loan associations and savings banks, and enabling them to expand credit and suspend foreclosures; agricultural credit banks which loaned to farmers; Reconstruction Finance Corporation (RFC) loans to banks, states, agriculture, and public works; spreading of work to prevent unemployment; the extension of construction and public works; strengthening Federal Land Banks; and, especially, inducing employers to maintain wage rates. Wage rates «were maintained until the cost of living had decreased and the profits had practically vanished...» (Rothbard (2000), pp. 321-322).

\footnotetext{
9 Higgs (1987), p. 173.
} 
Faced with these departures from the free market order, what is the State, epitomized by its President, to do? The reasonable reaction in front of the debacle of interventionist measures is not more interventionism, but cancelation of the interventionist measures that have caused social harm in the first place. From what we will see, not only didn't Roosevelt put out Hoover's fire, but he has even poured more gas on it. Instead of wondering whether Roosevelt got Americans out the Great Depression, we should ask: Has the Roosevelt Administration ever done anything of good economic consequence?

There is a plethora of legislative acts that the Congress has decreed, in some cases as a post-factum justification of Roosevelt's actions. We will review a series ${ }^{10}$ of decrees that illustrates the sheer size of Roosevelt's interventionism. They made such changes, "on such a scale and left such an enduring ideological residue that they represent a quantum leap of statism in American history.» (Raico, 2001).

The avalanche of interventionism could be categorized into several chapters: monetary-financial; labor and public works; agriculture; housing; taxation and redistribution; manufacture and industry. This categorization will allow for a theoretical interpretation, in light of economic theory, of some of the over forty decrees enumerated. Also, we will see what the actual consequences were.

III

THE MONETARY-FINANCIAL MEASURES

Economics teaches that any amount of extra money introduced into an economy by the government, through any channel, is going to distort the structure of relative prices and will practically ${ }^{11}$

10 Sources: The Real Deal: The Battle to Define FDR's Social Programs, An American Studies Website created by Paul Volpe, University of Virginia, http:/ / xroads.virginia.edu/ MA02/volpe/newdeal/intro.html (Accessed: May 25, 2009); Anderson (1979), Powell (2009).

11 To the unlikely extent that the monetary expansion is anticipated by the entrepreneurs and thus the interest rate reaches the same level it would have reached 
lead to a further unsustainable squandering of scarce and valuable resources by malinvestment in a production structure discoordinated to a greater degree than in the absence of monetary manipulation. The Roosevelt regime has worked under the sway of inflationism from its very inception.

Hoover ended his mandate in economic chaos. In January 1933, all over United States panic and bank runs were causing the disappearance of bank reserves into gold in circulation. A virulent wave of partial bank closures -imposed by state governorsculminated in Roosevelt's first economic measure: the instauration of a nationwide bank «holiday» starting March 6, 1933. Many say that the inauguration of his presidency with a banking holiday was inevitable. The entire monetary system was at risk of collapse, with ruinous consequences for the economy. Against this view, Murray Rothbard argues that in the 1933 bank run episode the United States faced a classic interventionist's fork:

Essentially, there were two possible routes. One was the course taken by Roosevelt; the destruction of the property rights of bank depositors, the confiscation of gold, the taking away of the people's monetary rights, and the placing of the Federal Government in control of a vast, managed, engine of inflation. The other route would have been to seize the opportunity to awaken the American people to the true nature of their banking system, and thereby return, at one swoop, to a truly hard and sound money.

The laissez-faire method would have permitted the banks of the nation to close-as they probably would have done without governmental intervention. The bankrupt banks could then have been transferred to the ownership of their depositors, who would have taken charge of the invested, frozen assets of the banks. There would have been a vast, but rapid, deflation, with the money supply falling to virtually 100 percent of the nation's gold stock. The depositors would have been «forced savers» in the existing bank assets (loans and investments). This cleansing surgical

in the absence of the expansion, the intertemporal malinvestment is avoided. See Hülsmann (1998). 
operation would have ended, once and for all, the inherently bankrupt fractional-reserve system, would have henceforth grounded loans and investments on people's voluntary savings rather than artificially extended credit, and would have brought the country to a truly sound and hard monetary base. The threat of inflation and depression would have been permanently ended, and the stage fully set for recovery from the existing crisis. But such a policy would have been dismissed as «impractical» and radical, at the very juncture when the nation set itself firmly down the "practical» and radical road to inflation, socialism, and perpetuation of the depression for almost a decade (Rothbard (2000), p. 329).

Although Rothbard's solution in this case is open to critique from his own intellectual camp - on ethical grounds - the HooverRoosevelt apparent consensus was clearly not preoccupied with the proper way of doing justice to the depositors when it closed the banks nation-wide. Rather, the purpose was to avoid a further run of gold reserves from the banking system and the associated prospect of prolonged and deepened deflation.

His action, ingeniously claiming justification from a law passed during the First World War, the Trading with the Enemy Act, was covered ex-post, on March 9, 1933, when Congress passed the Emergency Banking Relief Act. This act represents a stab in the back of the American citizen, marking a permanent encroachment on property rights. Besides further enforcing and extending an older privilege ${ }^{12}$ accorded to banks, shielding them from citizens' property rights in taking back their own gold, the act bestowed upon the President the power to manipulate the dollar definition of gold. The next measures in the monetary area were, in a logical continuity, aimed against the gold standard. In April $5^{\text {th }}$ and $19^{\text {th }}$ gold possession was deemed illegal and gold reclamation by private citizens was abolished. Thus, America was taken off the gold standard.

The Thomas amendment to the Agricultural bill, dating from April 20th, was intended at aggressive inflation: 6 billion of new

12 Huerta de Soto (2006), chapters 2, 3, and 8. 
dollars in purchases of government bonds and banknote printing and the power to devalue gold up to $50 \%$ were the main measures for increasing the monetary base and for further inflation.

In the battle against «lower-than-normal prices», the Roosevelt administration continued Hoover's war on financial speculation in general and short selling in particular. The Federal Securities Act from May 1933 and the Securities Exchange Act from June 1934 were aimed mainly at fighting price deflation in the primary and secondary financial markets. The demand for «truth in securities prospectuses» had quite obviously the effect of hampering the issue of new securities. The introduction of a bureaucratic agency, the Securities and Exchange Commission, to hunt for the practice of insider trading, to discourage short selling and generally monitor the market in Big-Brother fashion could not have other effects than leading to increased discoordination and inhibition of the credit market and, so, another step in the direction of general impoverishment.

The foreseeable effect of this type of regulation is wider fluctuation of prices, as the institution of short selling is known to mitigate price fluctuations ${ }^{13}$. Benjamin Anderson draws the verdict on the regulation and control against short-selling:

the Dow-Jones industrials rose from 108.64 on June 1, 1935, to 190.38 on August 14, 1937, and then dropped to 97.46 in March 31, 1938. This is not a brilliant record for a governmentally controlled, daily inspected, constantly managed stock market, designed to give protection to investors and to eliminate wide fluctuations in security prices (Anderson (1979), p. 448).

Roosevelt's freedom in gold manipulation was thwarted by government's long-term obligation to its citizens - e.g., gold bonds- and also by the citizens liberty to include gold clauses in private contracts. Therefore, on June $5^{\text {th }}$, he had Congress pass the abrogation of the gold clauses in contracts. According to Robert P. Murphy, ${ }^{14}$

\footnotetext{
13 Carden, Murphy (2008).

14 Murphy (2009), p. 129.
} 
This continued prohibition of gold clauses is significant, and reflects the ultimate objectives of the government...Americans were now entirely at the mercy of those controlling the printing press.

Another piece of financial legislation was the Glass Banking Act of June 16, 1933. It contains regulations against abuses of the «wild period» of 1924-29. However, it is considered a failure to strike at the «basic evil», the unsound FED policy, because it dealt with symptoms (such as securities underwriting and speculation). It decreed separation of commercial and investment banking, interdiction for banks to underwrite bonds except federal, state and municipal, interdiction of loans to banks officers and interdiction of interest payment on deposits. This particular act could be among the few, if not the only one, that contains elements compatible with financial normalcy. We are dealing here with provisions aimed at the elimination of the fraud of fractional reserve banking, namely the deliberate confusion of deposits with credit transactions: hence the interdiction of interest payments on deposits and the separation of commercial and investment banking. But it is only a half-baked act, as the federal reserve system of pyramidal monetary expansion was not affected by this kind of minor regulations. This separation left untouched the confusion of the two distinct activities traditionally performed by banks: on the one hand deposit banking, i.e., the business of guarding in toto, accounting and making payments with the money deposited and received by clients, on their behalf, and on the other hand credit intermediation, i.e., the business of buying credit from clients who save and selling it to clients who borrow. Both these activities continued to be performed by commercial banks after the passage of the Glass Banking Act. Tabarrok (1998) argues that the artificiality of the separation between commercial and investment banking is a result of the scheming rivalry between the two major special interest groups of the era, «the Morgans» and «the Rockefellers», rather than a product of principled policy.

However, some of the measures contained in this act could not possibly help with economic recovery. The introduction of the Federal Deposit Insurance Company was not in the least 
contrary to the inflationary drive of the banking system, since this kind of assurance of Fed rescue is creating a moral hazard towards more monetary expansion. We will analyze below the institution of deposit insurance, that continued its existence ever since.

The crowding-out of bond underwriting means that a relative burden was put on the issuing of bonds by the private sector and that the federal, state and municipal agencies could relatively more easily attract funds through the issuance of bank underwritten bonds.

While private gold redemption was abandoned, the national monetary and banking system was still exposed to gold discipline since the internal gold standard renunciation was deemed only a transitory measure and the Fed was internationally bound to buy back the dollars sold by the other national banks with gold. These "golden shackles» were further loosened on January 30, 1934, when the Gold Reserve Act fixed the devaluation of the dollar in terms of gold. The price of gold went from 20.67 dollars per ounce to 35 dollars per ounce. It meant a $69 \%$ increment of the monetary base.

Prior to this measure, Roosevelt backed temporarily Professor Warren, the «agricultural economist» with no monetary background, who came up with the idea of a gold variation program. He advised for the discretionary manipulation of the gold definition of the dollar. It was thought that dollar devaluation should turn internal prices up in paper dollar terms. Speculation thwarted this shortsighted initiative.

First of all, leaving aside for the moment all the complications introduced by the financial international setting at that time, even in the case of a purely paper money inflation the effects would come about after some time. Even if the market anticipates the coming inflation and the entrepreneurs know that they will have to charge increased prices in order to avoid capital consumption, there are several factors impeding instant price inflation.

First, there is the fact that new money is usually not uniformly dispersed by helicopter-like devices but introduced into the nexus of market exchanges at certain points - e.g., the Reconstruction Finance Corporation (RFC) was massively buying gold at increased 
dollar prices in the London market- and it takes time for them to reach the other market participants. Also, some of the market participants will never see their nominal income increase as a consequence of this monetary injection. This process described by Cantillon could theoretically be alleviated by the use of credit. However, in a private property order the means of avoiding monetary-induced losses is limited by the amount of real saving existing in the economy. The arbitrage in the time market will take the interest rate to such a height that some entrepreneurs, in spite of correct anticipation of the future purchasing power of the monetary unit, will realize that the interest rate at which they must borrow funds or take commercial credit makes them incur capital losses. The only option available for this class of entrepreneurs, if they are really alert and visionary, is to unwind their businesses in due time or, what amounts to the same measure, short sell the stocks of their own businesses. This is how the Cantillon effect works: a monetary-induced change in the price structure brings about a shift of capital and resources in the market, under all circumstances.

In the Rooseveltian manipulation case, the facts were very different from a situation based on private property. The banking sector had the privileged power to fabricate paper credit with no correspondent in increased savings. But it also was still under an international gold standard and this is one reason why credit manipulation was not as easy as nowadays.

What Roosevelt and his counselors should have had in mind, instead of lucky numbers ${ }^{15}$ - when arbitrary fixing, over breakfast in bed, the dollar definition of gold-, was the obvious peril of a speculative reserve drain and the subsequent further implosion of the inverted credit pyramid. Also, even with credit capacity intact, banking and the other entrepreneurs usually need the confidence of clear rules before starting risky new businesses by taking credit and biding up prices in factor markets.

The resulting market reaction to this gold fumbling was foreign exchange speculation in the London market. A lot of sellers of gold

\footnotetext{
${ }^{15}$ Flynn (1948), p. 57.
} 
were probably redeeming it from the other countries still on the gold standard (France, the Netherlands, Belgium, Switzerland) and selling it to the RFC at a higher dollar price in order to profit from a lagging exchange rate and a fixed gold definition at the other central banks. Also, we should keep note of the fact that the international monetary system was in a metamorphosis from the gold standard to the gold exchange standard, the latter including two paper currencies besides gold - the pound and the dollarinto the monetary base. Overall, the gold manipulation program led to the increase of Fed gold, and not to its decrease. The only notable effect, however, besides destabilizing the other national monetary systems pyramided on gold,${ }^{16}$ was a weakened dollar in foreign exchange, amounting to external dollar inflation. Commodities markets did not rise, maybe because the international trade was hampered by protectionism, maybe for still other reasons.

Further on, yielding to the silver interests and aiming at an even bigger increase of the monetary base and more paper money inflation on top of it, the Roosevelt regime came up with the Silver Purchase Act, passed by Congress on June 19, 1934. In this decree, the government was to buy silver at a price higher than the market price (50 cents per fine ounce). It was applied to the stocks of the silver speculators, not to coins or jewelry or newly mined domestic silver. The Treasury issued legal tender silver certificates, «redeemable on demand in silver dollars». According to Benjamin Anderson, ${ }^{17}$ this measure rendered the dollar weak in the foreign exchange market and some gold was exported until the exchange recovered. The long term effect was a massive accumulation of silver in the vaults of the American government and the increase of the world silver price.

Another step in monetary regimentation and control was the Banking Act of August 23, 1935. It revised the operation of the Federal Reserve System with the intention of bringing the member banks under the power of the Federal Reserve Board by

\footnotetext{
16 Anderson (1979), p. 343.

17 Anderson (1979), pp. 353-356.
} 
monopolization of the open market operations and a looser definition of the monetary base. It established federal deposit insurance for deposits up to 5000 dollars.

The most important aspect of this act was that it meant to increase the monetary basis, by extending the type of eligible assets from gold, papers secured by government bonds and short-term commercial paper (maturing at less than 90 days) to any kind of asset deemed «sound» by the Fed. Senator Glass initiated opposition and amended the bill to the effect that the maturity of these "assets secured to the satisfaction of the Fed" was to be extended to a maximum of 120 days and have a penalty rate of at least half percent over the usual discount rate. The Glass subcommittee succeeded also in putting the open market operations in the hands of an Open Market Committee in which the Board had only partial power.

From the perspective of a sound monetary policy, this kind of victory, where monetary inflation is to be done by the "Lesser Brothers» and not by the Big Brother himself is hardly a success. It may very well be that the moral hazard thus created leads eventually to an even bigger monetary expansion than under a system completely monopolized by a Central Bank. We should clarify here that although the Glass opposition succeeded in bringing about a less pernicious solution than the one initially designed by the opponents, the starting point of this reform was already a flawed arrangement. To the extent that the owner of a U.S. banknote - only international traders after march 1933had the right to demand gold on spot at face value - at face quantity, to be more precise- in exchange for their banknotes, the answer to the question of monetary base definition is blunt: only gold and nothing else, however liquid, should constitute the monetary base.

These were the main decrees defining the inflationary financial and monetary foundation on which the other pillars of economic planning came. 
IV

UNEMPLOYMENT AND THE MAKE-WORK «CURE»

Roosevelt begins his presidency in 1933 with 25\% of the workforce unemployed, as a consequence of Hoover's «laissez-faire» reaction to the 1929 crash. The recipe for reducing unemployment is closely related to the Keynesian idea of putting the necessary "purchasing power» in the hands of labor, that is, fiduciary money to increase real wages and thus to propagate the economic revival. Unemployment is surely a tragic situation for any unemployed person. But instead of letting the people enter into mutually advantageous exchanges with their private property and labor skills, that is, instead of letting the free market coordinate towards an economic recovery, Roosevelt chose further regimentation by having the federal, state and local agencies employ people with money coming mainly from the freshly gained inflation power of the Federal Reserve. In his inaugural address Roosevelt declared:18

Our greatest primary task is to put people to work. This is no unsolvable problem if we face it wisely and courageously. It can be accomplished in part by direct recruiting by the Government itself, treating the task as we would treat the emergency of a war, but at the same time, through this employment, accomplishing greatly needed projects to stimulate and reorganize the use of our natural resources.

Let's see what are the regulations issued for the planning of these problems. On March 31, 1933, Congress passes the Reforestation Relief Act, establishing the Civilian Conservation Corps (CCC). It provided work for young men in reforestation, road construction and developing national parks. Work camps began to spring up. Until 1941, three million people are reported to have worked on its projects. Historian Ralph Raico cites John A. Garraty to the effect that: ${ }^{19}$

18 Source: Franklin D. Roosevelt, Inaugural Address, March 4, 1933, as published in Rosenman (1938), pp. 11-16.

19 Raico (2001). 
Garraty was compelled to note the striking similarities between the CCC and parallel programs set up by the Nazis for German youth. Both

were essentially designed to keep young men out of the labor market. Roosevelt described work camps as a means for getting youth 'off the city street corners,' Hitler as a way of keeping them from 'rotting helplessly in the streets.' In both countries much was made of the beneficial social results of mixing thousands of young people from different walks of life in the camps.... Furthermore, both were organized on semimilitary lines with the subsidiary purposes of improving the physical fitness of potential soldiers and stimulating public commitment to national service in an emergency.

On May 18, Tennessee Valley Authority (TVA) is created as part of the public works program, to construct dams and power plants. On May 12, 1933, Congress passes the Federal Emergency Relief Act, which authorizes immediate grants to states for relief projects. On June 6, 1933, the National Employment System Act is passed. On June 16, on the final of the Hundred Days, the Public Works Administration is created through the National Industrial Recovery Act (NIRA). On August 5, Roosevelt establishes the National Labor Board introducing the «right» of collective bargaining in an attempt to boost union power and thus to raise wages. On November 8, 1933, the Civil Works Administration is created to give more work for the unemployed. On February 15, 1934, the brand new Civil Works Emergency Relief Administration is charged with the introduction of new programs. June 29, 1934 Roosevelt issues an executive order creating the National Labour Relations Board (NLRB). On April 8, 1935, the Emergency Relief Appropriation Act authorized almost 5 billion dollars for immediate relief and increased employment on projects such as the Works Progress Administration (WPA). This act is renewed in June 1938. On July 5, 1935, F.D. Roosevelt signs the National Labor Relations Act (Wagner-Connery) and in June 1938, Wages and Hours Act is passed in order to limit the work-week and increase the minimum wage. 


\section{$\mathrm{V}$ \\ AGRICULTURE: THE CULTIVATION OF CHAOS}

In 1933, the high tariffs stipulated by the Smoot-Hawley Act were depressing the internal agricultural market that was in great need of an international market. Instead of lowering the tariffs, Roosevelt thwarted all efforts for international cooperation by having Congress vote additional restrictions on imports (contained in the NIRA) just as Secretary Hull was participating at the London International Economic Conference. ${ }^{20}$ What followed was the high-frequency issuance of acts and creation of agencies aimed at internal planning and control of the agriculture.

It started with the Agricultural Adjustment Act ${ }^{21}$ of May 12, 1933. It stipulated the restriction of production and acreage, processing taxes, public acquisitions and subsidies in order to reduce production and stocks of «surplus» crops and thus increase the prices of agricultural products. Roosevelt is thus engaging in the continuation of the Hooverite "plowing-under» policy. At a time when millions of Americans were starving Roosevelt's counselors thought it was a brilliant idea to further impoverish the public by spending their money to increase the price of food, destroy crops already cultivated and turn mass-destroyed livestock into expensive fertilizer.

The Farm Credit Act of June 16, 1933 established the Farm Credit Administration to offer loans to farmers. It is continued through the Crop Loan Act from February 23, 1934. On April 21, 1934, the Jones-Connally Farm Relief Act is introduced for the extension of the Agricultural Adjustment Act, and on April 21, 1934 Congress passes the Cotton Control Act imposing quotas limiting the cotton production of various areas and individuals. On May 9, 1934 the Jones-Costigan Act authorizes controls on both cane and beet sugar as well as sugar imports. On June 28, 1934 two acts related to agricultural fascism are passed: the Taylor Grazing Act allocated around 8 million acres of public land

20 Anderson (1979), p. 326, Flynn (1948), p. 52.

21 Source: http://publicpolicy.pepperdine.edu/faculty-research/new-deal/ legislation/aaa051233.htm 
for grazing and the Tobacco Control Act set mandatory quotas limiting the production of tobacco.

VI

HOUSING

The 1920's bubble was also a housing bubble. Just like today, more credits related to the housing market were contracted than in the absence of the monetary expansion. This meant that some of the credits were unsustainable and could not be paid. Farmers were especially exposed and then hit by the crisis and the imposition of tariffs. Hoover, through his misguided measures, has created an incentive for farmers not to pay their mortgages. Faced with amplified mortgage defaults part of which were stimulated by the Hoover-era legislation, the Roosevelt regime created another series of laws to ease the conditions for bad debtors.

On June 16, 1933, Congress passes the Home Owners Refinancing Act to provide mortgage money and other aid to homeowners. It creates the Home Owners' Loan Corporation (HOLC). It will go out of business in June 1936 after providing loans for about one million mortgages. The Farm Mortgage Refinancing Act of January 31, 1934 is passed in order to assist farmers in refinancing their mortgages. On June 12, 1934 the Farm Mortgage Foreclosure Act is introduced in order to help farmers recover property lost to foreclosure. June 28, 1934 National Housing Act establishing the Federal Housing Administration (FHA) to insure loans for construction, renovation or repairs of homes and the Federal Farm Bankruptcy Act places a moratorium on farm mortgage foreclosures. On May 1, 1935, Roosevelt created the Resettlement Administration (RA) to help farm families relocate and furnish them with loans and new projects. On February 10, 1938, the FHA Administrator chartered the Federal National Mortgage Association (Fannie Mae), of present notoriety. 
VII

TAXATION AND REDISTRIBUTION

Second to the leap in monetary socialism, this is perhaps the area where the most enduring damage to the economic life was made.

On August 14, 1934, FDR signs the Social Security Act guaranteeing pensions to those retiring at 65 with contributions from both employees and employers. Also provides financial aid to dependent children and blind people and establishes a system of unemployment insurance. According to John T. Flynn, the contribution for the old-age pension for retired workers amounted from 1934 until 1938 to $6 \%$ of payroll, shared by both employers and employees. In 1938, the Congress reduced the rates to $2 \%$, at least until the time of his writing. ${ }^{22}$ This redistribution was ultimately a measure bolstering unemployment because employees are the ones suffering the net effect of any kind of payroll taxes. The employers are pressured by the market to control the cost of wages in accordance with labor's discounted marginal value product, so that gross wages, including all kinds of tax costs, must be kept below that amount or workers must be marginally unemployed.

According to Benjamin Anderson, United States featured in 1934 the highest taxes in the world in the upper brackets. He offers the example ${ }^{23}$ of the combined federal and New York State personal income tax rates in 1934: they ranged from $13.5 \%$ for incomes of $\$ 20,000$ to $69.9 \%$ for incomes of $\$ 5,000,000$. Besides these income taxes, the estate and inheritance taxes took from $0.75 \%$ out of property priced at $\$ 20,000$ and ranging to no less than $60.5 \%$ out of properties priced at $\$ 50,000,000$. On August 30, 1935 Congress passed the Revenue Act, increasing taxes on inheritances, gifts and higher income individuals. It introduced drastic increases in personal income tax rates and estate taxes; it proposed federal inheritance tax that was eventually dropped from the bill. The result was, again according to Anderson's

\footnotetext{
22 Flynn (1948), pp. 59-60.

23 Anderson (1979), p. 366
} 
analysis, a modification of the personal income tax range from to $2.45 \%$ for incomes of $\$ 4,000$, to $83,2 \%$ for incomes of $\$ 4,000,000$. Estate taxes, on the other hand, ranged from $1 \%$ for estates up to $\$ 50,000$, to $72 \%$ for estates priced at $\$ 150,000,000$.

In June 1936, the Congress approved a $\$ 1,773,000,000$ soldier bonus out of easy money. In July, 1936, the undistributed profits tax was introduced as a war on savings under the sway of Keynesian ideas, according to which savings are bad for the economy when they go to hoards and not to investment. As Anderson argues, ${ }^{24}$ it had little effect since corporate savings kept being, at least on paper, very low or even negative since 1929. In June 1937, another $\$ 556,158,000$ was given for the soldiers, in cash and bonds of US Life Insurance Fund. ${ }^{25}$

VIII

\section{MANUFACTURE AND INDUSTRY}

On June 16, 1933, Congress passes the National Industrial Recovery Act. The Roosevelt era was an era of distrust in the private property order and of government's ambition to replace private initiative with national planning. Historian John T. Flynn argues that Franklin Delano Roosevelt saw in Mussolini's fascist social regimentation a good example for United States. Out of the New Deal forest of agencies, NRA is outstanding for its purposes, mostly similar to Mussolini's corporatist regime. While President Hoover has organized a host of conferences urging the owners of the industries to collude voluntarily in order, on the one hand, to decrease unemployment (by keeping wages up!) and, on the other hand, to keep prices from falling and start increasing them again to precrash levels, the Roosevelt Administration aimed at the same results through this veritable «crown» of the Hundred Days. In

24 Anderson (1979), pp. 372-382. See table on page 377. On page 376, Anderson states that «beginning with 1930 there had been an uninterrupted series of years where corporate surpluses were depleted instead of being added to, years of gigantic corporate deficits instead of additions to corporate surpluses».

25 Anderson (1979), p. 428. 
spite of the existing anti-trust policy of punishing monopolists, it was high time, according to Roosevelt's Brain Trust, to mandate «cooperation instead of competition». Agreements for limited production, cross-industry control of prices, outlawing of child labor, a maximum of 40 hours of work per week, and a minimum wage ranging from 12 to 15 dollars were desired. These objectives were going to be achieved «voluntarily» through the codes that each industry needed to write for itself, under the guidance of the NRA. In the words of John T. Flynn: ${ }^{26}$

The NRA provided that in America each industry should be organized into a federally supervised trade association. It was not called a corporative. It was called a Code Authority. But it was essentially the same thing. These code authorities could regulate production, quantities, qualities, prices, distribution methods, etc., under the supervision of the NRA.... The second phase was to sign up separate industries into the corporative code authorities. Over 700 codes were created. Business men were told to come to Washington and «write their own tickets», as Roosevelt said. They could scarcely believe their ears.

The voluntarism of the NIRA is of Orwellian double-talk fame. The industry owners who would not comply «voluntarily» faced prison and public humiliation.

On February 2, 1934 Roosevelt established by executive order the Import-Export Bank of Washington to encourage commerce between the U.S. and foreign nations. Protectionism is another bad policy of the New Deal. One of the oldest truths established by economists is that the country engaging in free trade stands to gain irrespectively of how the other countries are responding to this free-trade policy. Since any voluntary exchange is benefiting the parties engaged, it is of no consequence whether this exchange will be followed by another exchange or not. Instead of abandoning protectionism unilaterally and thus alleviate the Depression Roosevelt's New Deal increased the protectionist measures.

\footnotetext{
${ }^{26}$ Flynn (1948), pp. 43-44.
} 
The NIRA was accompanied by several other measures. ${ }^{27} \mathrm{On}$ August 26, 1935, FDR signed the Public Utilities Act giving federal agencies new powers of regulating the gas and electric companies. The Robinson-Patman Act, introduced in 1936 as an amendment to the Clayton Antitrust Act, was designed to protect small grocery stores from the bigger chain stores that were in a position to make economies of scale and transfer them to the consumers through reduced prices. The Miller-Tydings Retail Price Maintenance Act, dated August 17, 1937 was also designed to come to the rescue of the small businesses. On June 23, 1938, the Congress passed the Civil Aeronautics Act, a cartelization instrument, protecting established flight companies from potential competition.

IX

\section{OVERALL EFFECT: FASCISM AND DESTITUTION}

As we can see from the laws analyzed above, Roosevelt era meant a considerable push forward in the ratchet-like ${ }^{28}$ evolution towards overall government planning of the economy. As is apparent from the plethora of decrees enumerated and analyzed above, the actions toward the professed government take-over of the economy did not develop according to a road-map well thought in advance, but rather in an erratic zigzag fashion. Historians suggest this was due to Roosevelt's reported lack of fundamental political values and also determined by what we can identify as the logic of political competition. Even if Roosevelt would have held staunch political beliefs and even if his surrounding advisers would not have had differences of opinion and even if all the American citizens would have been voluntarily mobilized under his government program, it has been theoretically shown that it is impossible to plan an entire economy as a private company. It is therefore, no wonder and no accidental reason that the whole scrutinized period evoked ${ }^{29}$ a

\footnotetext{
27 Powell (2009).

28 Higgs (1987).

${ }^{29}$ Flynn (1948), p. 42.
} 
vast hippodrome, that hectic, whirling, dizzy three-ring circus with the NRA in one ring, the AAA in another, the Relief Act in another, with General Johnson, Henry Wallace and Harry Hopkins popping the whips, while all around under the vast tent a whole drove of clowns and dervishes-the Henry Morgenthaus and Huey Longs and Dr. Townsends and Upton Sinclairs and a host of crackpots of every variety-leaped and danced and tumbled about and shouted in a great harlequinade of government, until the tent came tumbling down upon the heads of the cheering audience and the prancing buffoons.

Furthermore, Flynn distinguishes between three sub-deals into the Roosevelt New Deal. The first one is characterized by the most overt drive toward fascism with host of regulations and public projects, the second by the emphasis on spending and the third by the regimentation of the Second World War. However, the legislation considered unconstitutional by the Supreme Court was swiftly replaced by Congress under the sway of the Roosevelt Administration with Acts bearing a different name but essentially the same content. ${ }^{30}$ It may be argued that the enduring general recipe for recovery was sketched along the lines of what will come to be known as the Keynesian solution: to kick-start the economy into a spiral of rising prices up to the high mark of 1929 and beyond. This was to be achieved by increasing nominal and real wages, reducing unemployment by public projects and thus confer purchasing power in the hands of the work-force. Then, to the extent that consumers would be hoarding this excess purchasing power, the government was supposed to intervene so as to substitute private investment with public spending. In the end in different ways the prices of agricultural and manufactured goods in USA had to be brought in relative harmony with each other, that is, to give more relative height to agricultural prices, and to a higher overall level. The results were far from satisfactory (Chart 1).

The New Deal was the era of contradictory rules and arbitrariness. The NRA was pushing for cartelization while the prior anti-trust

30 See, for example Cole, Ohanian (2001), p. 13. 
CHART 1

GDP IN BILLIONS OF CURRENT DOLLARS

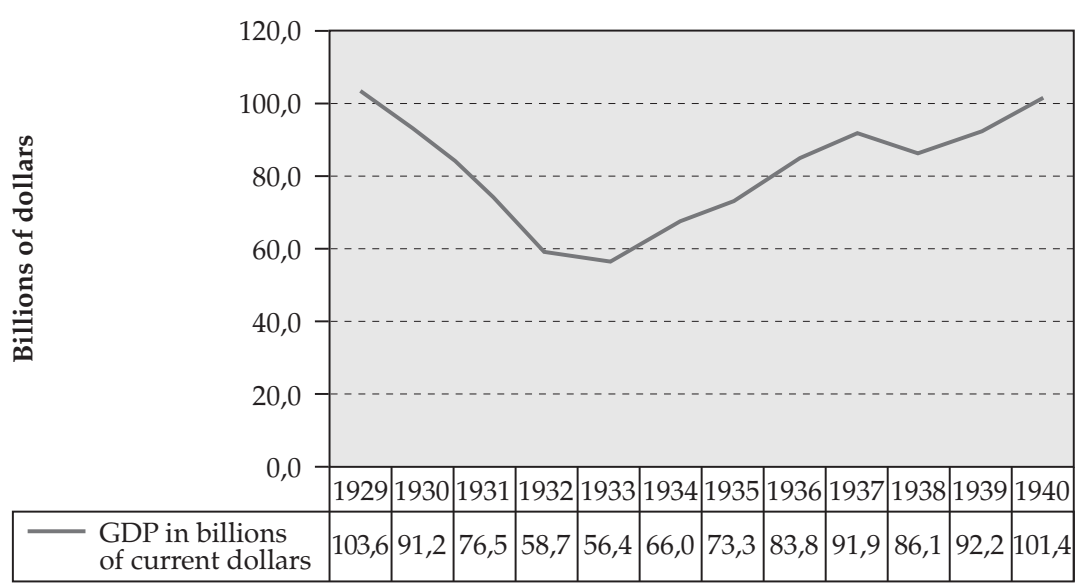

Source: U.S. Department of Commerce.

laws forbade it. The inflationary policy contradicted with the idea of a fixed exchange rate inherent in the international gold exchange standard that US joined de facto after going off the gold standard. The internal cartelization, production micro-management and price control, on the one hand, and the augmentation of the supply of paper dollars, on the other hand, were destined to introduce wide-spread economic chaos. The intentions of introducing financial conservatism through the Glass Banking Act and the close financial scrutiny by the Securities and Exchange Commission could not square well with the Thomas Amendment and the introduction of the Federal Deposit Insurance. The AAA was spurred by «acute economic emergency» to fight the "severe and increasing disparity between the prices of agricultural and other commodities» ${ }^{31}$ and bring about a relative increase of agricultural prices as compared to industrial prices. Meanwhile,

31 The Agricultural Adjustment Act , http:/ / publicpolicy.pepperdine.edu/facultyresearch/new-deal/legislation/aaa051233.htm 
the NRA was accusing the "national emergency productive of widespread unemployment and disorganization of industry» to introduce the solution of forced cartelization and collective bargaining against «destructive wage or price cutting». ${ }^{32}$ Above all, the spirit of arbitrariness and bureaucratic absolutism was the characteristic of the Roosevelt period: ${ }^{33}$

New rules and new procedures were announced with great frequency, creating violent speculative disturbances and creating new business uncertainties.

Robert Higgs investigated on the possibility that this state of affairs introduced what he calls «regime uncertainty» as a cause of depressed private investment. Short of complete lack of knowledge about the level of enforcement of the above measures, I contend that there is no need to look at proxy measures for increased uncertainty (such as opinion polls) ${ }^{34}$ to know the effects of the New Deal. Unless the tens of Congress Acts were dead letter and all political activity was unheeded by the public and businesses and any enforcement effort made by the government, we can be sure simply by way of deduction that the economic outcome could not be better than it would have been in the absence of these measures. It must have been far worse, actually.

But how much worse and how did each of these Acts and their subsequent enforcement affect the general state of affairs is the task of historical investigations, and arguably much more difficult to gauge. What is important at this point is that not one of the pieces of legislation mentioned above can be credited as a genuine anti-depression, pro-recovery measure. As we have seen, even in the case of the Glass Banking Act of 1933, the search of financial discipline is going nowhere. I think it can be said, by looking exclusively at the legislative heritage of the Roosevelt era, that nothing good could come out of it. We can have now a

32 The National Industrial Recovery Act, http:/ / publicpolicy.pepperdine.edu/ faculty-research/new-deal/legislation/nra061633.htm

33 Anderson (1979), p. 337.

${ }^{34}$ However, Higgs' article has tremendous illustrative power. Higgs (1997). 
quantitative look at the economic picture produced by the social struggle of the Roosevelt years.

We can see below a graphic representation of unemployment in the Hoover-Roosevelt New Deal. It is the most compelling illustration of the New Deal's suppressive effect. Roosevelt succeeded in keeping the unemployment at very high levels. In his book about the Great Depression and the New Deal, Robert P. Murphy looks comparatively at the contemporary situation of the unemployed in Canada. He observes ${ }^{35}$ that

during the (peacetime) heyday of the New Deal from 1934 to 1941, U.S. unemployment, on average, was 5.9 points higher than Canada's. Thus, if one tries to excuse the lingering unemployment of the 1930s on «external shocks» outside of Roosevelt's control, we must nonetheless conclude that the Canadian government did a better job handling such shocks. (Incidentally, the Canadians did not institute a «Northern New Deal» during the 1930's.)

Moreover, if we take unemployment as a measure of resource idleness and squandering, rather than a measure of hunger and psychic suffering, then we have to keep in mind that a lot of unemployment was masked by the measures and projects listed above. Higgs argues that, given the work-spreading schemes prevalent in those times, a correct measurement of labor would be taking into account the man-hours worked. ${ }^{36}$ It would therefore be interesting to add all the men-hours spent in the make-work schemes to the official unemployment data (while subtracting them from the employment). How much more would real unemployment be then? The man-hours thus calculated could be differentiated from official unemployment figures in order to stress the gravity of the squandering that these make-work schemes made of the scarce natural resources and strenuously accumulated capital at such times. Those resources and capital would have otherwise been left to the calculative allocation of the private property order (Chart 2).

\footnotetext{
35 Murphy (2009), pp. 103-104.

36 Higgs (2009), p. 2.
} 
Chart 2

UNEMPLOYMENT AND ITS TREND

IN THE GREAT DEPRESSION

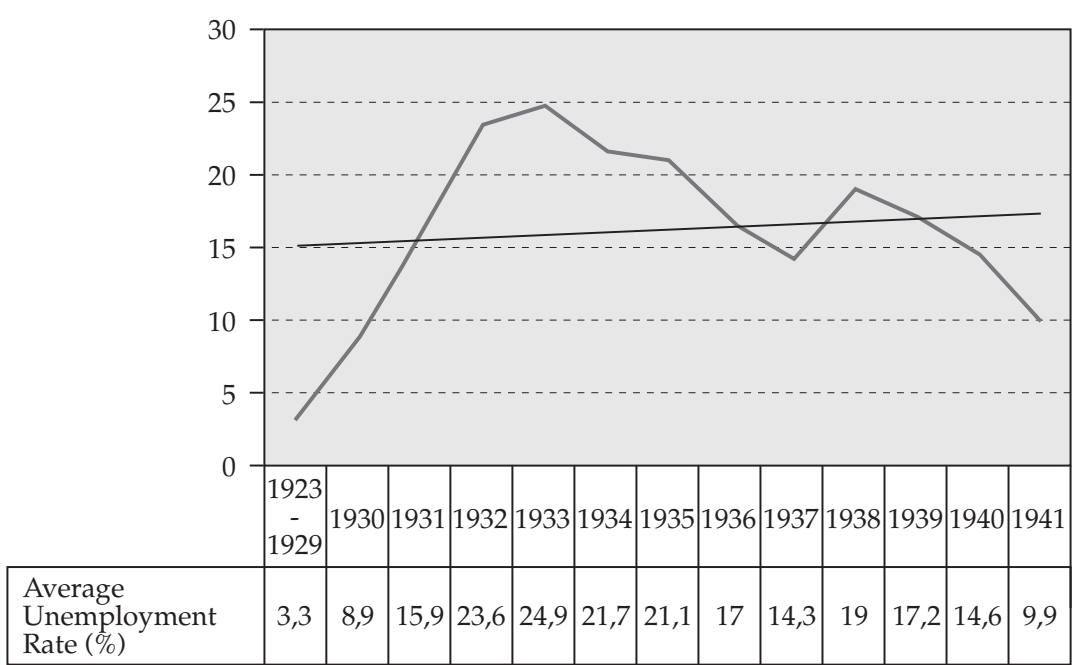

Source: Murphy (2009), pp. 99-100.

To get the government junk-work out of the way Higgs studies the evolution of private nonfarm hours worked in the period. He concludes: ${ }^{37}$

Private nonfarm hours, however, did not exceed their 1929 level until 1942, when Americans were energetically building up the war-supply industries and a gigantic complex of military facilities to accommodate an armed force that eventually exceeded 12 million men and women in uniform. As late as 1939, Roosevelt's seventh year in the presidency, private nonfarm hours were 16 percent below their total in 1929-and about 21 percent below the trend high-employment level for 1939 (computed on the assumption of a constant rate of growth of such hours between 1929 and 1948). Perhaps no other single comparison expresses so succinctly, so unambiguously, and so irrefutably the New Deal's failure to bring about full economic recovery. Moreover, in 1939,

37 Higgs (2009), p. 6. 
private nonfarm hours no longer represented nearly 75 percent of the total national hours worked, as they had in 1929, but only 69 percent-surely a move in the wrong direction with regard to restoring the pre-Depression level of economic well-being.

Indeed, the idea that the New Deal wreaked havoc rather than recovery begins to grip ${ }^{38}$ the positivistic mind. Harold L. Cole and Lee E. Ohanian, after taking a «theory-free» look at the Great Depression policies observe ${ }^{39}$ that

The recovery from the Great Depression was weak despite rapid productivity growth, and was accompanied by significant increases in real wages and prices in several sectors of the economy. A successful theory of the recovery from the Depression should account for persistent low levels of consumption, investment, and employment, the high real wage, and the apparent lack of competition in the labor market. We developed a model with New Deal labor and industrial policies that can account for sectoral high wages, a distorted labor market, and depressed employment, consumption, and investment despite normal productivity.

Then they engage upon building a model — where «[t]ime is discrete and denoted by $\mathrm{t}=0,1,2, \ldots \mathrm{n} »$ and «[t]here is no uncertainty», to start with! — to test whether and to which extent the NIRA and NLRA, with their collective bargaining and cartelization enforcement, brought about a prolongation of the depression. Their

results suggest that New Deal policies are an important contributing factor to the persistence of the Great Depression. The key depressing element behind these policies was not monopoly per se, but rather linking the ability of firms to collude with paying high wages. Our model indicates that these policies reduced consumption, and investment about 14 percent relative to their competitive balanced growth path levels. Thus, the model accounts for about half of the continuation of the Great Depression between 1934 and 1939.

38 DiLorenzo (2004).

39 Cole, Ohanian (2001), p. 51. 
In a recent Wall Street Journal article ${ }^{40}$ Cole and Ohanian reaffirm their findings about the New Deal. This time they state that the depression was prolonged with 7 years because of the «bad part of the New Deal». Thus, rather than bringing recovery, Roosevelt's bad measures produced the "recession within the depression» of the 1937. They conclude that «Wholesale government intervention can - and does- deliver the most unintended of consequences». However, the reforms they propose are not adequate and their articles show that the limited positivistic analysis hamper their further judgment of the "good part of New Deal». We will see below that the proposed reforms are inadequate.

Although we could not gather the banking and other financial data necessary for extending Rothbard's thorough analysis of money and banking from the interval 1921-1929 further into Roosevelt's years, we can see from the graphic below that the Roosevelt era was characterized by unleashed inflation of the money stock (what the Fed now calls monetary base) (Chart 3).

The money stock calculated here by the Treasury amounts to gold, silver, minor coin and different types of paper money. While we have a measure of money in circulation, we do not know how much of the money deposited at the treasury were actually used for government transactions and also, we do not know how much was pyramided -in the form of demand deposits, time deposits, deposits of saving-and-loan associations, life insurance surrender liabilities, and other instruments functioning as monetary substitutes - on the sums outside of the treasury and not in circulation. The money stock has evolved from 9 billion dollars in 1932, to 23.8 billion dollars in 1939, a 264\% total growth, at $15 \%$ annually on average.

The true money supply is difficult to gauge for reasons deeper than lack of banking data. Thus, the confusion introduced gradually between time and demand deposits puts the historian in the difficult position of guessing at the intentions of the actors owning the different types of deposits at banks and other financial institutions. He cannot know whether a person holding a deposit views it as a saving or as holding of cash. Therefore, even if we

${ }^{40}$ Cole, Ohanian (2009). 


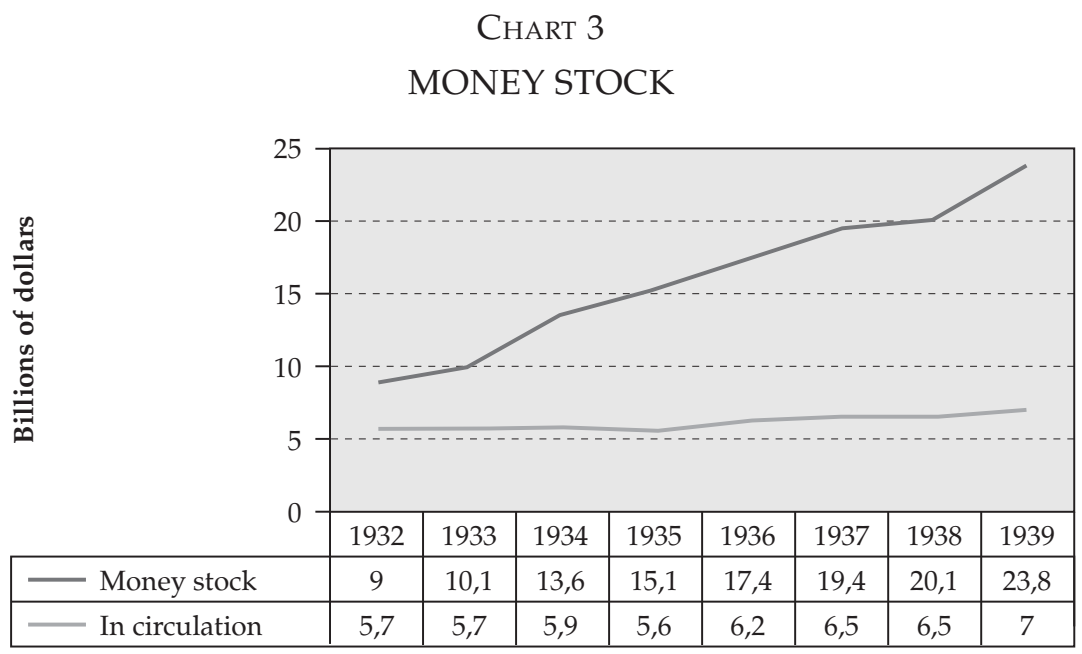

Source: U.S. Treasury Department.

observe banking contracts and actual practice, until the market demonstrates the preference to hold money in action, ${ }^{41}$ we cannot presume strict operational knowledge of the volume of money in society.

Despite gold inflows into U.S. and the $69 \%$ increase of the dollar definition of gold in 1933, the gold coverage of the above money stock (monetary base) never exceeded 70 percent (Chart 4).

Below we can see the main indexes of the stock market (Chart 5).

Historical prices do not serve for theoretical tests but for illustrative purposes. On both graphics, but especially on Standard \& Poors one could distinguish between two phases in the New Deal: one of relative struggle, in 1933 and 1934, then the beginning of what could be called a «deflated bubble» and then the crisis of August 1937, marking the beginning of the depression within the depression. The stock market crash came after several months of struggle between Roosevelt and the Supreme Court. Although it seemed like the Supreme Court defeated the "packing» offensive, in reality the judges became much more lenient (some giving up

${ }^{41}$ Huerta de Soto (2006), p. 792. 
CHART 4

PERCENTAGE OF GOLD IN MONETARY BASE

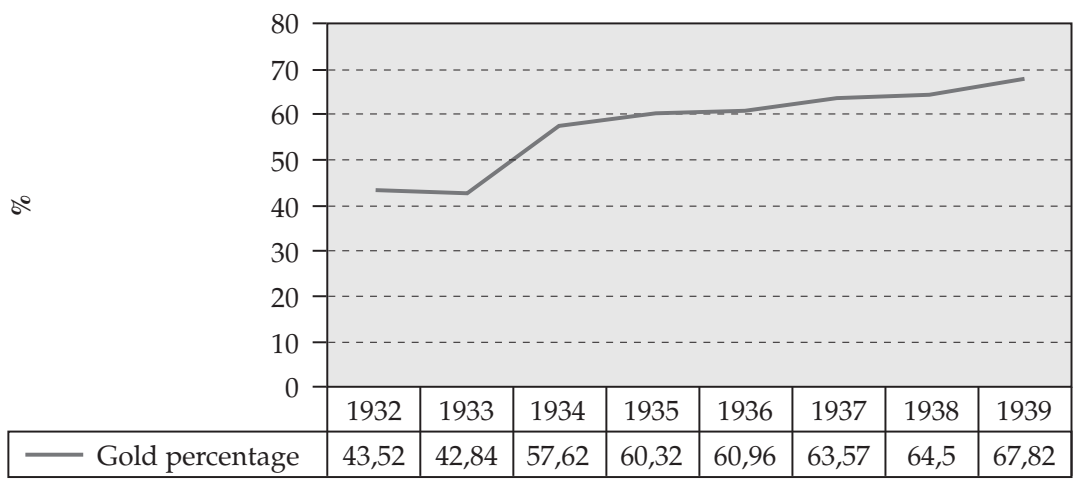

Source: U.S. Treasury Department.

CHART 5

STANDARD AND POORS 500 COMPOSITE INDEX

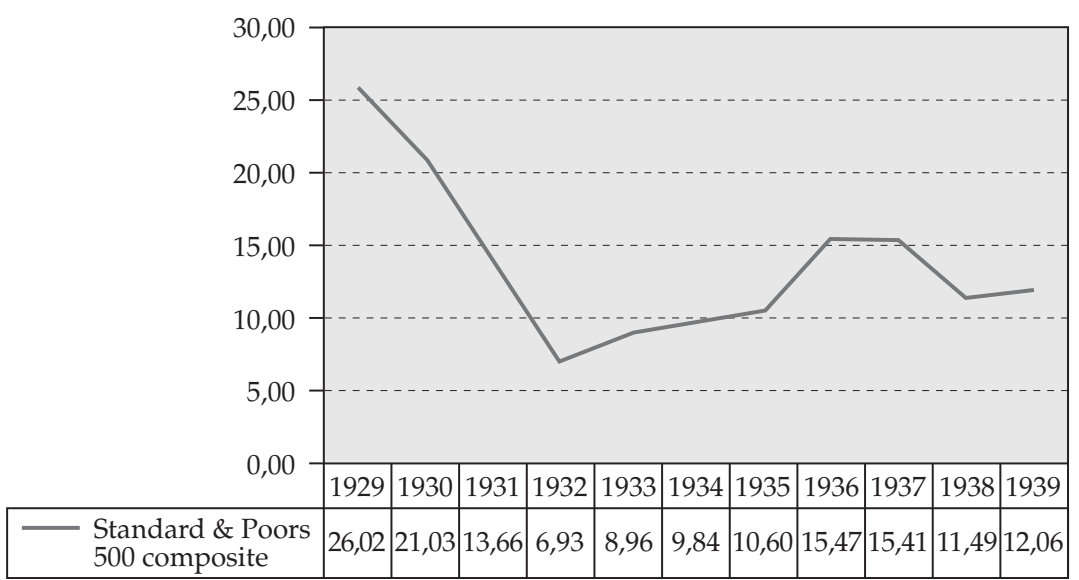

Source: U.S. Bureau of Economic Analysis.

the struggle altogether and choosing retirement) and began passing Roosevelt's legislation. The summer of 1936 was marked by the passing of NLRA (Wagner), which gave renewed power to the unions. Anderson considers that this event, combined with further 
loss of business confidence lead to retrenchment of private investment and decline of economic activity.

It may be noted that it is much more difficult to see historical traces of the business cycle under all the aforementioned disturbing factors. Rather than ample booms and resounding busts, what we should expect under a situation where monetary expansion is combined with wide regulation and government planning, is a continuous slump. This was Roosevelt's real deal for America (Chart 6).

Where regime uncertainty, credit expansion and economic fascism make private investment retreat from the economy, government takes over. We will look at government depredation of the economy by continuing the analysis ${ }^{42}$ done by Rothbard in America's Great Depression (Table 1).

CHART 6

DOW-JONES

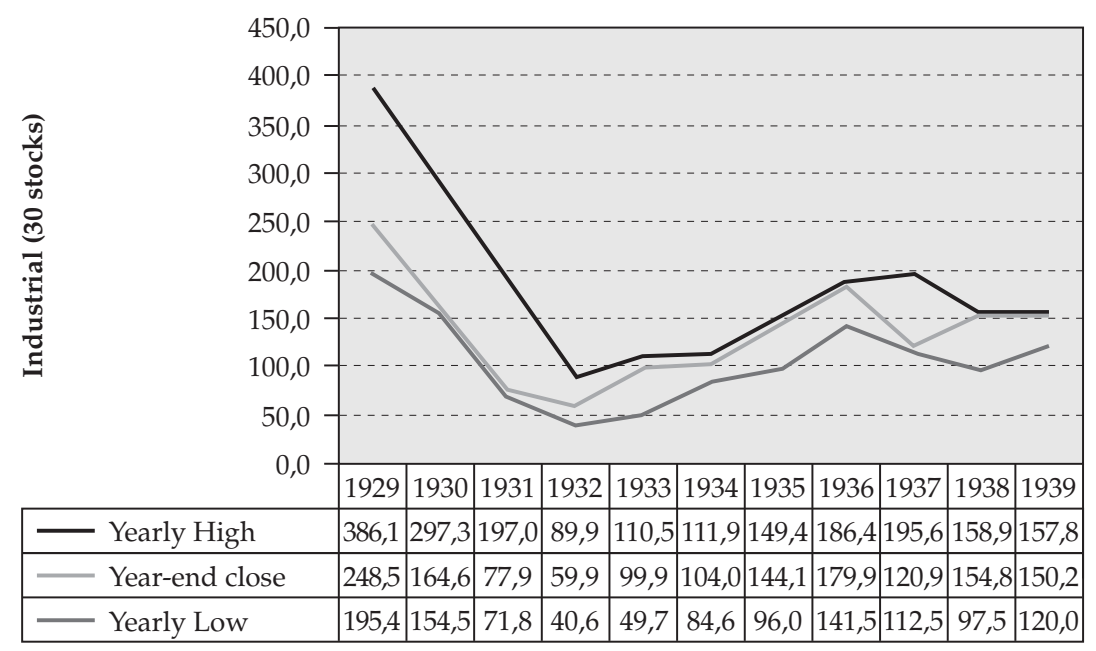

Source: U.S. Bureau of Economic Analysis.

42 See Rothbard (2000), page 255 and Annex. We have encountered the following difficulties: Government enterprises mixed into private product, subsides consolidated with government enterprises deficit, interest paid and interest received represented as remainder value. No de-homogenization was performed. 


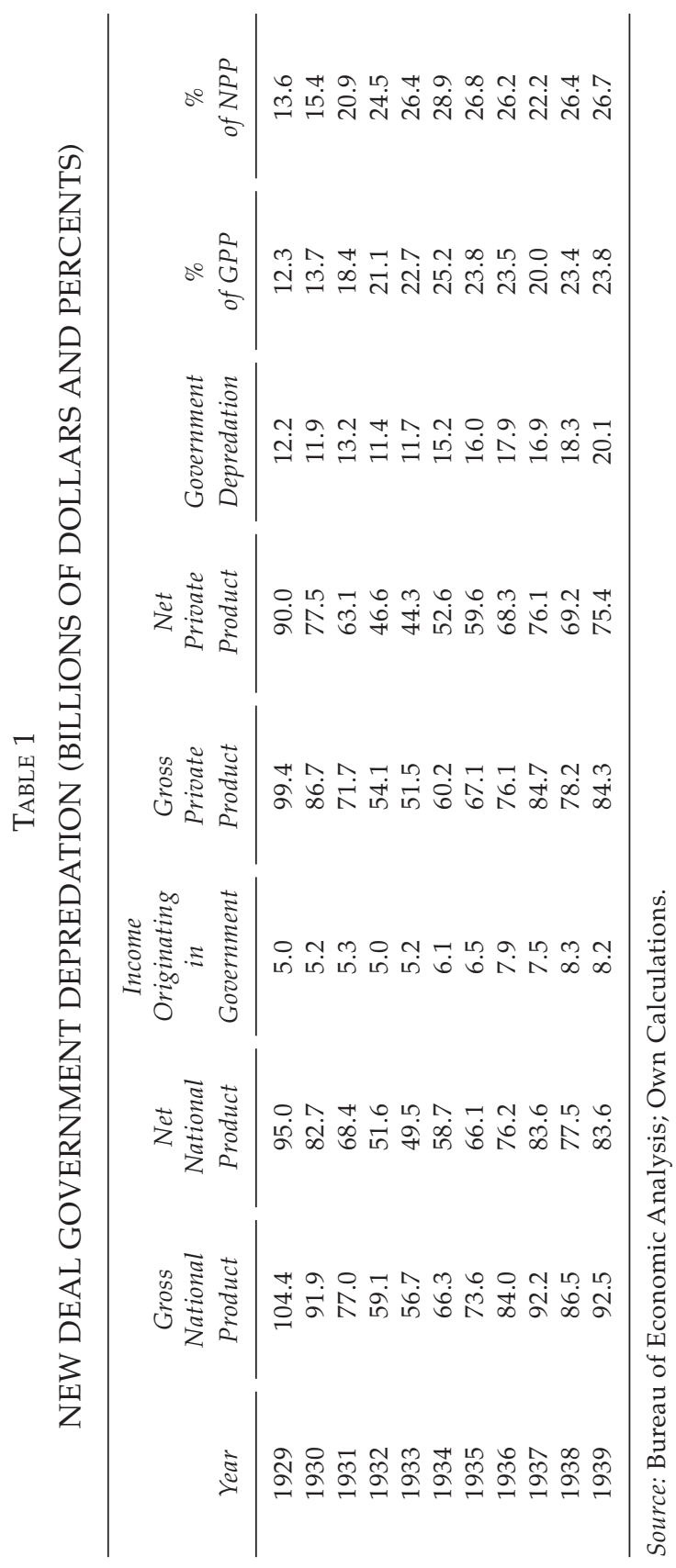


Although our calculations do not reach Rothbard's level of sophistication, one can observe that there is a good approximation of his results for government depredation in the years from 1929 to 1933. Given the extra difficulties imposed by the economic regulations of the era (government controlled prices) on the usual lack of relevance of official statistics - due to biased sampling, aggregation and Keynesian-oriented methodology and concealment-, this confirmation of the trend first highlighted by Rothbard should be considered more than satisfactory (Chart 7).

Following this trend, we can see that Roosevelt not only did not reduce the size of Federal and State governments relative to the private sphere, but also increased it significantly. Again, we can distinguish here a first phase of the New Deal, marked by the rampant fascism of the Hundred Days, taking government's size in 1934 to a record high for the decade. Then we see a relative decline, coinciding with the inflation of the depressed bubble, from 1935 to 1937. The tax hike operated in the Revenue Act of 1935 does not seem to have lead to a proportional increase of government revenue. After 1937, the New Deal regains its strength,

Chart 7

NEW DEAL GOVERNMENT DEPREDATION

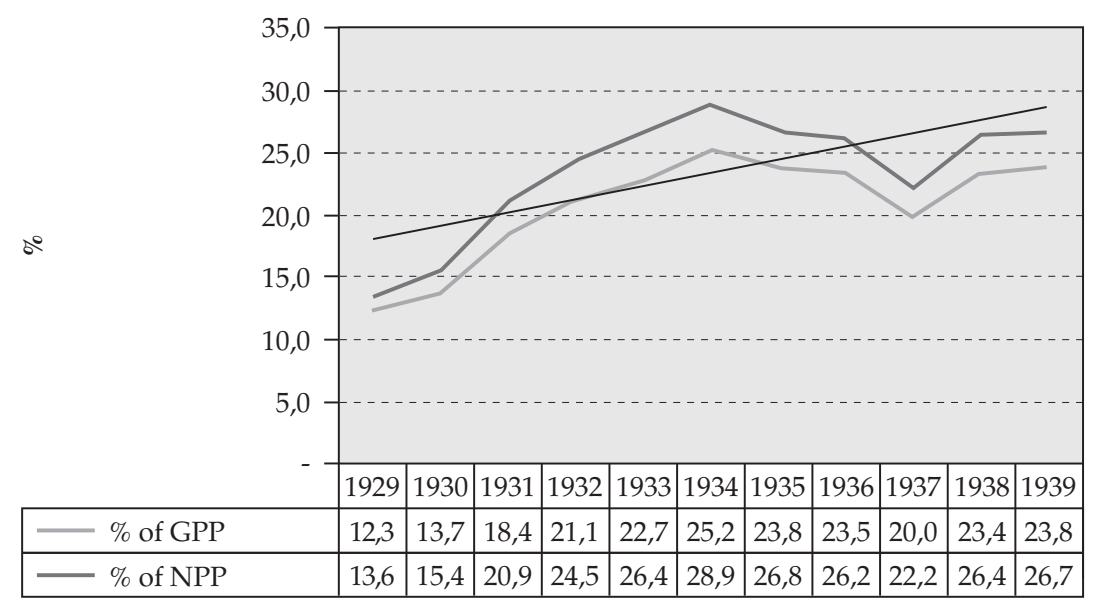

Source: Own calculations from Bureau of Economic Analysis data. 
ending the decade in what the advocates of Big Government could consider a resounding success: a doubling of the relative size of government, growing from around an eight part to around a quarter of the private sphere. And, again, these conclusions are drawn from relatively toothless data.

The New Deal was there to stay. Many of the inroads made by government into the American private property order with Roosevelt at the helm left permanent traces. Robert Higgs ${ }^{43}$ makes a summary of New Deal's uninterrupted legacy:

[M]any of the institutional innovations of the 1930s remain embedded in the socioeconomic order today: acreage allotments, price supports, and marketing controls in agriculture, detailed regulation of private securities markets, extensive federal intrusion in union-management relations, enormous governmental lending and insurance activities, the minimum wage, national unemployment insurance, Social Security pensions and welfare payments, production and sale of electrical power by the federal government, fiat money wholly without commodity backing - the list goes on and on.

\section{$X$ \\ SOME ALTERNATIVE THEORIES \\ OF THE GREAT DEPRESSION}

It is very important to reveal the weaknesses of many explanations of the Great Depression since this event is claimed as the «founding myth of Keynesism, of macroeconomy, of interventionism» (Spiridon (2005), p. 15).

Most scholars group theories alternative to the explanation given above in two main categories: Keynesian and Monetarist. Both these paradigms share in empiricism, pretending to take a theory-free look at the data. The empiricist approach is falsely based on the idea that the blank human mind can face reality and

${ }^{43}$ Higgs (1987), p. 159. 
then derive valid causal relationships. The truth is the other way round: reality is explained through prior causal relationships. ${ }^{4}$ We may join George Selgin ${ }^{45}$ in saying that

Mises would have insisted that all of the lasting discoveries of the classical and neoclassical economists it the realm of pure theory were in fact results of the method described by praxeology; but this was by no means the acknowledged procedure of those schools of thought. [...].

Indeed, denial of apodictic certainty involves a denial of necessity and causation that «would lead to the abandonment of all theoretical and historical pursuits» (Selgin (1990), p. 51, n. 17). This is precisely the reason why we continue to take into consideration these theories, although we accuse them outright of unrealistic and disingenuous procedures. Thus, these economists find themselves in a state of methodological sloppiness. Many seem to share a view of the human person as an «interchangeable black box» ${ }^{46}$ whose main raison d'être is to be introduced into mathematical models sporting absurd assumptions, or used as a government revenue maximization function. This approach gives such a broad theoretical leeway that some social thinkers working under its sway derive ridiculous conclusions while others reach a fairly good interpretation of reality. Therefore, besides separating alternative theories into Keynesian and Monetarist, we can separate them into completely untenable, on the one hand, and acceptable with amendments, on the other.

The classical monetarist position on the Great Depression is best represented by Milton Friedman and Anna G. Schwartz, in their renowned treatment, The Great Contraction. While Friedman is generally perceived as an advocate of laissez-faire ${ }^{47}$ he and Schwartz advance here the quintessential monetarist thesis that

\footnotetext{
${ }^{44}$ Mises (1985), Hoppe (1995).

${ }^{45}$ Selgin (1990), p. 22

${ }^{46}$ Expression used by Cristian Comănescu, cited in Topan, Foreword to Mises (2007),

47 This view is subject to contention. See Rothbard (2002).
} fn. 9 . 
the main cause of the Great Depression was the Fed's inability to continue a price stabilizing inflation policy and to avoid deflation.

Price stabilization is a misguided policy. Increasing productivity matched by politically increased inflows of money tend to lead to a parallel malinvestment into unsustainable channels. The errors thus induced are revealed later and further inflows of money after the crisis cannot possibly revert a waste of real scarce resources but will seed further discoordination and waste.

Nevertheless, Friedman and Schwartz make a series of historical correlations - with the help of «natural experiments» 48 that serve as benchmarks for testing hypotheses- showing that depression is indeed correlated with prior monetary deflation. All problems would have gone away had Hoover been able to reinflate the monetary bubble. The conclusion is that the central bank should be led by a charismatic person with strong interventionist powers that should adapt the monetary expansion to the growth of productivity. Huerta de Soto ${ }^{49}$ accuses Friedman of neoclassical kinship with the Keynesians, denoted by his lack of a capital theory. Because he cannot understand the havoc wrought by monetary expansion into the intra- and inter-temporal coordination of the capital structure, he cannot understand that even with a moderate inflation the economy suffers for no reason. Indeed, the fear of deflation is widely shared across the discipline but for no good reason. Beautiful profits can be made and harmonious growth can be attained in the context of decreasing prices. Entrepreneurs have the ability to anticipate spreads among falling prices and engage in arbitrage. Temporary differentials can develop between sinking prices for final goods and increasing prices for factors of production, and so much more in the case of a general decreasing tendency. Joseph T. Salerno ${ }^{50}$ points out that Friedman's hypothesis is shattered to pieces by a recent study on the correlation between deflation and depression. The empirical research ${ }^{51}$ of Atkeson and

\footnotetext{
48 Bernanke in Friedman, Schwartz (2009), p. 247

49 Huerta de Soto (2006), chapter 8.

50 Salerno (2004), cited in Spiridon (2005).

51 Atkeson, Kehoe (2004).
} 
Kehoe show that in the Great Depression only 8 out of 16 countries showed a correlation between deflation and depression, while exclusive of that period, out of 73 episodes with deflation only 8 have a correlated depression. That means in $90 \%$ of the cases, Friedman's hypothesis is rejected. The authors observe, on the other hand, that «inflation is actually negatively related to output growth in the post-WWII data.» (Andrew Atkeson; Patrick J. Kehoe, 2004, p. 5) Salerno concludes about the Friedman-Schwartz hypothesis that

With the validity of their correlations now called into serious question by a study using well over 100 years of data from seventeen different countries, we may yet see the deflation-depression link follow another supposedly ironclad empirical relation, the Phillips Curve, into well-deserved oblivion (Salerno, (2004)).

His monetary position aside, Friedman gives a negative verdict ${ }^{52}$ to a large part of Roosevelt's New Deal:

Roosevelt's policies were very destructive. Roosevelt's policies made the depression longer and worse than it otherwise would have been. What pulled us out of the depression was the natural resilience of the economy + WW2. [...] The problem was that you had unemployed machines and unemployed people. How do you get them together by forming industrial cartels and keeping prices and wages up? That's what Roosevelt's policies in the New Deal amounted to. Essentially, increasing the role of government, enhancing the monopolistic position of labor, and creating [...] the equivalent of price fixing cartels made things worse. So most of his policies were counterproductive.

However, the above passage denotes another wide-spread fallacy ${ }^{53}$ about the Great Depression, namely that it ended with the advent of the Second World War.

52 Hawkins (2003).

53 For a critique of this idea, see Higgs (2009) and Murphy (2009). 
This monetarist thesis is further nuanced by a series of authors. The most famous of them is Ben Bernanke. He claims that, in addition to the monetary scarcity created by the unwillingness of the Fed to inflate - that he identifies along with Friedman and Schwartz as the main cause of the Great Depression-, there were other, additional effects caused by the "problems in the financial sector.» He accuses the lack of a «theory of monetary effects on the real economy than can explain protracted nonneutrality». This statement could be strikingly surprising to the student of the Austrian theory of the business cycle. Nevertheless, let us see Bernanke's arguments. ${ }^{54}$

The disruptions of the 1930-1933 [...] reduced the effectiveness of the financial sector as a whole in performing these services. As the real costs of intermediation increased, some borrowers (especially households, farmers, and small firms) found credit to be expensive and difficult to obtain.

First, let us observe that Bernanke makes an economies-of-scale argument: because of relatively increased overhead cost of borrowing it became less profitable to lend small amounts and more profitable to lend large amounts. He would have to clear out of his demonstration's path the well-known «trickle down ${ }^{55}$ practice, noted by Higgs:

[T] he agencies channeled federal money into large institutions rather than directly into the hands of the suffering masses. Hoover's strategy $[\ldots]$ was to feed the sparrows by feeding the horse.

This strategy would suggest «crowding out» rather than perverse economies of scale. But even if it would be so, Bernanke does not suggest that it would have been preferable to hit the big businesses instead of the small ones. He views the problem in the overall insufficiency of credit.

\footnotetext{
54 Bernanke (1983), p. 257.

55 Higgs (1987), p. 165.
} 
Therefore, what Bernanke states in this article is that monetary deflation per se had a first negative impact on output, but the persistence of monetary deflation has more to explain. In other words, the banking industry was not so swift as to inundate the market with paper credit irrespective of the actions of the Fed. Here he seems to second Rothbard in reaching the conclusion that the uncontrollable part of the banking system worked against Fed's resolution to reinflate. ${ }^{56}$ Only that, against Rothbard, Bernanke assumes that pump priming is desirable (as Friedman apparently demonstrated). In addition Bernanke suggests that banks had legislative and bureaucratic barriers to expand credit, e.g. bankruptcy proceedings.

Bernanke shifts between two concepts under the «nonmonetary» label. First, nonmonetary effects understood as that part of the multitude of consequences of monetary-driven changes that is not explained by the Friedman-Schwartz correlations. They are monetary in origin, but do not coincide with what Chicago monetarism understands usually as monetary. Second, he derives a notion of opportunity cost under the expression "cost of credit intermediation" (CCI). This notion is also monetary in the sense that the CCI is not divorced from the banking realities and it is the product of an economy operating with money and calculating in monetary prices. But the CCI cannot be directly seen in realized prices. This is counterfactual analysis proper. This second notion is much akin to the subjective opportunity cost used in what we consider to be the correct economic analysis. Let us see where it leads.

After stating in mainstream slang what would amount to a correct conclusion from an implicit time-preference theory of saving: the "pure substitution effect (of future for present consumption)» (p. 267), Bernanke goes on to state: ${ }^{57}$

....an increase in the cost of credit intermediation reduces the total quantity of goods and services currently demanded. That is, the aggregate demand curve, drawn as a function of the safe rate, is shifted downward by a financial crisis. In any macroeconomic

\footnotetext{
56 Rothbard (2000), Salerno (1999).

57 Bernanke (1983), p. 268.
} 
model one cares to use, this implies lower output and lower safe interest rates.

Now, «any macroeconomic model» built in the conditions of a capital theory vacuum leads to the stated conclusions. But if one uses the realistic concept of a capital structure, the perspective changes radically and renders the last statement plainly wrong. Increased saving and lower "aggregate» consumption mean higher availability of labor, natural resources and produced goods for production processes to feed on now and yield later in the final goods markets, for increased abundance. Just as Bernanke admits, credit was indeed available, but only for production processes considered reliable by the bankers: «money was easy for a few safe borrowers, but difficult for everyone else» (p. 266).

Moreover, since Bernanke is so apt as to understand that not all economically relevant events can be grasped by combing through realized prices and that the whole economic picture is completed by considering what was not seen, one can not avoid thinking how important a correct capital theory would be. Maybe with a capital theory at his disposal he would have second thoughts about the idea that 1933 meant a turn toward recovery, rather than a false start spurred by devalued paper, conserving the errors manifested in the capital structure and leading towards more discoordination. Why, then, praise the intensified seeding of greater subsequent capital destruction?

Let us now join Bernanke in making the completely absurd assumption that all the financial resources possessed by the agents of the financial sector are at their free disposal, irrespective of private property contractual terms, as he does, for example, by choosing to consider the relevance of a «ratio of loans outstanding to the sum of demand and time deposits.» (See legend to table on p. 262) The bankers' judgment about the best destination of «their» resources, held as universally valid until the crisis, is suddenly found wanting during and after the crisis for their ghastly impulse to scramble for their own liquidity.

The solution to this paradox lies in recognizing that economic institutions, rather than being a «veil», can affect costs of transactions 
and thus market opportunities and allocations. Institutions which evolve and perform well in normal times may become counterproductive during periods when exogenous shocks or policy mistakes drive the economy off course (p. 275).

The negative role of the gold standard with its incorrectly ascribed inherent instability, active still at international level after its 1933 internal repudiation, is now transferred to the free but inefficient market. Fed's tightwad partners in credit expansion were no longer reliable. The regressions show it now and the «providential» president knew it then. So Bernanke identifies the solution: Roosevelt's FSLIC, HOLC, RFC, to the rescue of the credit-dry market:

To the extent that the home mortgage market did function in the years immediately following 1933, it was largely due to the direct involvement of the federal government. Besides establishing some important new institutions (such as the FSLIC and the system of federally chartered savings and loans), the government «readjusted» existing debts, made investments in the shares of thrift institutions, and substituted for recalcitrant private institutions in the provision of direct credit. [...I]t seems safe to say that the return of the private financial system to normal conditions after March 1933 was not rapid; and that the financial recovery would have been more difficult without extensive government intervention and assistance. ${ }^{58}$

We have here post-monetarism in a few words: the economy needs markets free of regulations and bureaucracy and that suffices as long as prices are stable under a moderated inflationary regime. But let a crisis come and the judgments based on private property arrangements, with their «nonmonetary» credit-draught effects are to be overruled by the direct might of the Treasury and its annexed Federal Reserve.

This is exactly what happened since September 2008 with Bernanke governing the Fed. The interpretation he gives of the Great Depression is utterly wrong. It is a false rationale to put

58 Bernanke (1983), pp. 273-274. 
a more interventionist situation in place of prior inefficient interventionist arrangements.

To summarize, the deflation, or lack of inflationist adjustment of money and credit, has the effect of throwing the economic machine in disarray. This is the Friedman-Schwartz thesis. It was proved wrong time and again, by theory and by history. But even if the Fed had been more than willing to crank out money and credit in the Great Depression, and Rothbard has proved beyond doubt that it made desperate efforts to do it, the architecture of the monetary and banking system allowed for a «schizoid» behavior.

The Fed controlled a primary inverted pyramid, printing paper dollars in excess of the backing volume of gold. Then, the rest of the banking industry was supposed to further pyramid «deposits» of various kinds as a liability against gold and paper. This latter part of relatively independent member banks and a plethora of small and autonomous «unit» banks should have indulged in the whims of the Fed and abstain from accumulating excess reserves, injecting credit into the economy instead. It prudently didn't.

The grand Federal Reserve System was not versatile enough and this is what Bernanke bemoans when he accuses nonmonetary effects of the financial crisis. It did not irrigate the money markets as it should and this deepened the Great Depression. This is what he meant when he apologized famously about the role of the Federal Reserve: «I would like to say to Milton and Anna: Regarding the Great Depression. You're right, we did it». ${ }^{59}$

His response to the credit friction was radical monetary aggression. The golden privilege ${ }^{60}$ of the banking class, privilege extended by the robbery of people's gold in 1933, could be insufficient in times of need. The exit pointed rather to the direct involvement of the federal government by all type of interventions. The society of private property owners, with their «exogenous» prudence regarding their labor and material wealth are not to be

59 Stated at a Conference to Honor Milton Friedman's 90th birthday. See Bernanke in Friedman, Schwartz (2009), p. 247.

${ }^{60}$ Huerta de Soto (2006). 
deemed a sufficient reason to stop the crusade lead by the President and his «sage» counselors.

Another explanation of the Great Depression is related to what could be called «the new macroeconomics of anticipation». Bernanke is once again ${ }^{61}$ at it:

[L]ow and stable inflation has not only promoted growth and productivity, but it has also reduced the sensitivity of the economy to shocks. One important mechanism has been the anchoring of inflation expectations. When the public is confident that the central bank will maintain low and stable inflation, shocks such as sharp increases in oil prices or large exchange rate movements tend to have at most transitory price-level effects and do not result in sustained inflationary surges.

The decades of macroeconomic modeling assuming a convenient representative agent have gone. Now it is time for macroeconomics to postulate an equally unrealistic concept of human rationality, as in rational expectations. Policy can no longer ignore the fact that agents anticipate. Anticipations are a real phenomenon and their role in the formation of prices or on the effects of economic policies is a legitimate concern for the economic theoretician. However, the above passage is symptomatic for the prevailing literature on rational expectations. What we are dealing with here is a fallacy cubed. The concept analyzed is the formation of subjective value - an ordinal phenomenon - with respect to a future configuration of reality. Not even in the case of one person studied separately could the external observer offer a pattern of how his valuations will change over time. To say something to the contrary is an elementary fallacy. Subjective valuation also means the value some person attaches to a good cannot be compared with the value other person attaches to the same good. We already have tremendous problems when we consider that intrapersonal and interpersonal valuation processes can be studied and introduced

${ }^{61}$ Bernanke (2004), p. 214. 
in economic modeling. ${ }^{62}$ That would be a fallacy squared. But the worst error comes when one assumes away the freedom of human choice, because that is precisely what we are talking about when discussing «expectation anchoring». The cubing of the fallacy comes with the idea that valuation, or choice, as manifested in anticipations, or expectations, can somehow be predicted, measured, aggregated and then controlled indirectly, though different political measures. Man's freedom of choice is in fact rendered illusory under this arrangement.

Thus, expectations are «rational» as long as the public behaves according to the postulated model or the desired public policy. When human liberty plays out the events in the undesired direction, then «rational» expectations evaporate, anticipations are actually unhinged, irrational and a source of exogenous shocks, carrying the blame for the failure of the Procustean economic modeling. We can see that under the analytical framework of rational expectations the human actor does not escape the fate of being an interchangeable black box in macroeconomics. The rational expectations theory should be interpreted as just another decoy before the eventual loss of credibility of an older erroneous paradigm. We can join Nikolay Gertchev in saying that

It is evident that rational expectations are a catch-all hypothesis, which may indiscriminately cling to any model in order to justify its conclusions as being derived directly from human rationality. It is sufficient to postulate beliefs about the actual relation between economic variables, and then to presume these beliefs rational, in order to arrive at the conclusion that the relation is true and objectively revealed immediately. The RE hypothesis [...] goes much beyond its purpose. It does not circumscribe the real influence of expectations, it postulates that everything depends upon expectations. However, rational expectations does not explain why this is so, it merely claims that subjective beliefs shape reality in the pattern presumed by the model-builder. The RE hypothesis thus greatly contributes to the persisting split of

62 On interpersonal comparisons of utility and their implications for neoclassical modeling, see: Leoni, Frola (1977), Block (1999), Hülsmann (1999), Guerrien (1993). 
economic science in various schools, each finding support in this approach of modeling expectations. It is nevertheless evident that the presumed relationship between beliefs and reality is unsustainable. ${ }^{63}$

Another example of this set of arguments focusing on the idea of managing anticipation is revealed by Temin and Wigmore in their effort to explain the Great Depression and justify a certain type of political action, in the article titled The End of One Big Deflation. ${ }^{64}$ They state that nothing really explains the turn in the year 1933 better than a regime change bringing along a change of public perception about the political determination to devalue the dollar and impose all the other measure thus swinging the economy out of depression. Economic recovery thus depended on Roosevelt's credibility. They work on the false assumption that deflation implies depression. From their perspective, as long as there is inflation, big taxation and big spending, expectations must go along. A proof of expectations changing for the better is the rise of the stock market. Economics seems a lot easier when one can recite the expectation mantra: all general increases in price mean a change in expectations for the better and thus sustainable growth.

Of course, all action is directed toward the future, it anticipates, and therefore all changes in prices can be interpreted as an effect of changing expectations. However, to say that increased prices are the effect of a regime bent on devaluation and inflation only amounts to a tautology. Temin and Wigmore can say about the Great Depression that the

value of the dollar [is] a key index of the Roosevelt administration commitment to its new policy regime. When he hesitated expectations fell and production faltered. Fortunately, the dollar resumed its fall and the recovery was not aborted (Temin, Peter; Wigmore, Barry A., 1992, p. 352).

63 Gertchev (2007), p. 327.

64 Temin, Wigmore (1992). 
The stake of the expectation macroeconomics is to show that inflationism changes expectations about the course of the real economy, as opposed to the nominal, but since it relies on prices to measure expectations it cannot show that. It can only demonstrate that it can swirl around in circular reasoning.

As we have seen, a more realistic view of the Great Depression is held by Cole and Ohanian. Their model suggests that the effects of NIRA alone have prolonged the depression with so much as 7 years. However, they consider that there still was a «good part of the New Deal» and plead for keeping in place institutions such as regulation of the financial and manufacturing sectors, anti-trust policies, increased public revenues and spending and «specific» planning of stimulus packages. Thus, Social Security, deposit insurance and the SEC should be here to stay.

Regarding wide-spread regulations and anti-trust, suffice it to say that interventionism is unstable. Its inherent dynamic asks for complete retraction or otherwise it leads to more interventionism and ultimately to full-blown socialism. The advocates for regulation, therefore, have ultimately two choices: the private property order or the socialist chaos. A case in point is FDIC (The Federal Deposit Insurance Company). We have said above that deposit insurance spurs already existing profligacy in banking. Prior to FDIC, the banks were unstable because they were enjoying the privilege of appropriating the property of the depositors as if it was an unowned resource. They were thus already engaging in a fraudulent conduct that led to further economic woes in the form of economic cycles. The FDIC was the next step in the dynamic of banking interventionism and in exacerbating the problems, by letting the taxpayers support the deposit losses that were, until then, the responsibility of the bankers. Under FDIC, the individual banker would not extend credit according to what he perceives as the maximum level allowed by his resources, but would extend it according to the level of bail-out he expects to obtain from the deposit «insurance» funds guaranteed by the state.

Therefore, the only laws that should be left in place are the laws protecting private property. Such a system would also imply the abolishment of the fractional-reserve banking and thus deposit insurance would be a private matter, not a source of moral hazard. 
While it may be argued that insurance and old age pensions are welcome and should be as widespread as possible, the architecture of the Social Security is nothing but a big redistribution arrangement. Building pension funds through insurance companies means authentic saving, whereas the state social security is taxation with another name. Robert Murphy clarifies:

However, the crucial difference between Social Security and a genuine retirement plan is that through decades of legitimate savings and investment, retirees in a private system have provided more capital equipment for the younger workers who take their place. Their savings enhance the productivity of the next generation of workers, and so there is a greater total crop out of which the retirees get their cut. In contrast, under FDR's scheme, FICA payroll deductions are spent the moment the government receives them [...and] simply used to enlarge the government's consumption (Murphy, 2009, pp. 139-140)

What is left of the Cole and Ohanian recommendations, then, is taxation and redistribution, to increase revenues and specifically plan the stimulus packages. The only problem is that this recommendation in itself would amount to bringing through the back-door all the measures criticized before. If government regulation and planning of cartels, prices and wages is destined to prolong depressions by entire years, why would the forceful depredation of private funds and their redirection into channels considered better by the government apparatus, but obviously not by the free market, be any better? Bureaucracy cannot lead the market to a situation considered better by the public at large, and many times not even by the members of the bureaucracy. It is paradoxical, then, to address the government for pro-market measures when it is the spring of arbitrary social conduct leading to injustice and impoverishment, not to speak of added immorality. Rather, the solution to the Great Depression and any depression will come about through the real framework of social harmony, the free-market based on private property. 


\section{BIBLIOGRAPHICAL REFERENCES}

Anderson, B.M. (1979 [1949]): Economics and the Public Welfare, Indianapolis: Liberty Press.

AtKeson, A. y Kehoe, P.J. (2004): «Deflation and Depression: Is There an Empirical Link?», Research Department Staff Report 331, 1-13.

BERNANKE, B.S. (2004): «Friedmans's Monetary Framework: Some Lessons», Free To Choose Conference Proceedings (pp. 207-214). Dallas: Dallas Fed.

- (1983): «Nonmonetary Effects of the Financial Crisis in Propagation of the Great Depression», American Economic Review, American Economic Association, vol. 73(3), pp. 257-76, June.

BLOCK, W. (1999): «Austrian Theorizing: Recalling the Foundations», The Quarterly Journal of Austrian Economics, vol. 2, n. ${ }^{\circ}$, Winter, pp. 21-39.

CARDEn, A. y MurPhy, R.P. (2008, October 10): «The SEC Short Sells Us Down the River», LewRockwell.com, http://www. lewrockwell.com/orig3/carden3.html; accessed: 2009-06-15.

Cole, H.L. y Ohanian, L.E. (2009): «FDR Prolonged the Depression», The Wall Street Journal, February 3, p. 15.

- (2001): «New Deal policies and the persistence of the Great Depression: a general equilibrium analysis», N. ${ }^{\circ}$ 597, Working Papers, Federal Reserve Bank of Minneapolis, http: / / www.econ.yale.edu/seminars/echist/eh02/ ohanian-021008.pdf; accessed 2009-06-08

ComAnesCu, D.C., (2008): «Is There a Libertarian Eschatology?» http://MisesRomania.org/489/. accessed 2009-06-15.

DiLorenzo, T. (2004): «The New Deal Debunked (again)», Mises Daily, http:/ / mises.org/daily/1623; accessed: 2009-05-25.

FlynN, J.T. (1948): The Roosevelt Myth. New York: The DevinAdair Company.

Friedman, M., y Schwartz, A.J. (2009): The Great Contraction 19291933. Princeton and Oxford: Princeton University Press.

Gertchev, N. (2007): «A Critique of Adaptive and Rational Expectations», Quarterly Journal of Austrian Economics, vol. 10, pp. 313-329. 
Guerrien, B. (1990): L'économie neo-classique. Paris: La Découverte. Romanian translation: Economia neoclasică. București: Humanitas, 1993.

HAwKINS, J. (2003): «An Interview With Milton Friedman», Right Wing News (Conservative News and Views), http://www. rightwingnews.com/interviews/ friedman.php; accessed 2009-06-08.

HigGS, R. (2009): «A Revealing Window on the U.S. Economy in Depression and War: Hours Worked, 1929-1950», Libertarian Papers 1, 4, 1-12, ONLINE AT: www.libertarianpapers.org; accessed 2009-06-08.

- (1997): «Regime Uncertainty. Why the the Great Depression Lasted So Long and Why Prosperity Resumed after the War», The Independent Review, Vol. I (N.. 4), 561-590, Spring.

- (1987): Crisis and Leviathan. New York and Oxford: Oxford University Press.

Hoppe, H.-H. (2006): «The Justice of Economic Efficiency». In H.-H. Hoppe, The Economics and Ethics of Private Property (pp. 331-338). Auburn, ALA: Ludwig von Mises Institute.

- (1995): Economic Science and the Austrian Method. Auburn, ALA.: The Ludwig von Mises Institute.

- (1989): A Theory of Socialism and Capitalism. Boston: Kluwer Academic Publishers.

Huerta de Soto, J. (2006): Money, Bank Credit, and Economic Cycles. Auburn, Alabama: Ludwig von Mises Institute ( $2^{\text {nd }}$ edition, 2009).

- (Spring 2004): «La teoría de la eficiencia dinámica», Procesos de Mercado: Revista Europea de Economía Política, 11-71.

Hülsmann, J.G. (2008): The Ethics of Money Production. Auburn, Alabama: Ludwig von Mises Institute.

- (1999): «Economic Science and Neoclassicism», The Quarterly Journal of Austrian Economics, vol. 2, n.․ 4, Winter, pp. 3-20.

- (1998): «Toward a General Theory of Error Cycles», Quarterly Journal of Austrian Economics, vol. 1, n.․․ 4, Winter, pp. $1-23$.

LeONI, B. y Frola, E. (1977): «On Mathematical Thinking in Economics», Journal of Libertarian Studies, vol. 1, n.. 2, pp. 101-109. 
Mises, L. von (1998): Human Action (Scholar's Edition). Auburn, ALA: Ludwig von Mises Institute.

- (1985): Theory and History. Auburn, Ala.: Ludwig von Mises Institute.

- (1944): Bureaucracy; Romanian translation: Birocrația și imposibilitatea planificării raționale in regim socialist. București: Institutul Ludwig von Mises România, 2007.

Murphy, R.P. (2009): The Politically Incorrect Guide to the Great Depression and the New Deal. Washington, DC: Regnery Publishing.

PowelL, J. (2009): «How FDR Promoted Price-Gouging», LewRockwell.com, March 31, http://www.lewrockwell.com/ orig4/powell-jim7.html; accessed: 2009-06-09.

RAICO, R. (2001): Fascism Comes to America (FDR - The Man, the Leader, the Legacy). http:/ /www.lewrockwell.com/raico/ fdr-toc.html; accessed: 2009-06-09.

Rosenman, S., ed., (1938): The Public Papers of Franklin D. Roosevelt, Volume Two: The Year of Crisis, 1933, New York: Random House.

Rothbard, M.N. (2008): The Mystery of Banking. Auburn, Alabama: The Ludwig von Mises Institute.

- (2004): Man, Economy, and State with Power and Market (Scholar's Edition). Auburn, Alabama: Ludwig von Mises Institute.

- (2002): «Milton Friedman Unravelled», Journal of Libertarian Studies 16, n. $\stackrel{\circ}{4}$, 37-54, Fall.

- (2000): America's Great Depression. Auburn, ALA: The Ludwig von Mises Institute.

- (1998): The Ethics Of Liberty. New York and London: New York University Press.

- (1996): «Economic Depressions: Their Cause and Cure». In The Austrian Theory of the Trade Cycle and Other Essays. Auburn, Alabama: Ludwig von Mises Institute, pp. 58-81.

SALERNO, J.T. (2004): «Deflation and Depression: Where's the Link?», Mises Daily, August 6, http://www.mises.org/ story/1583; accessed 2009-06-06.

- (1999): «Money and Gold in the 1920s and 1930s: An Austrian View», The Freeman, 49, 10, October. 
Selgin, G.A. (1988): «Praxeology and Understanding», Review of Austrian Economics, vol. 2, n.․ 1, pp. 19-57.

SPIRIDON, M. (2005): Ciclul in teoria economica modernă (The Cycle in Modern Economic Theory-Doctoral Thesis). Bucharest: Romanian Academy, National Institute for Economic Research.

TABARROK, A. (1998): «The Separation of Commercial and Investment Banking: The Morgans vs. The Rockefellers», The Quarterly Journal of Austrian Economics, vol. 1, n.․․ 1, pp. 1-18.

Temin, P. y Wigmore, B.A. (1992): «The End of One Big Deflation». In B. Eichengreen, Monetary Regime Transformations, Aldershot, England: Edward Elgar, pp. 335-354. 